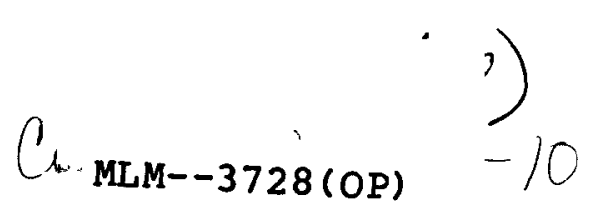

DE92 004004

\title{
MOISTURE MONITORS FOR THE TRITIUM EMISSIONS REDUCTION FACHITY
}

\author{
William H. Hedley, Dennis J. Gault, and Robert L. Mielke \\ EG\&G Mound Applied Technologies* \\ P.O. Box 3000 \\ Miamisburg, Ohio 45343
}

(513) $865-4020$

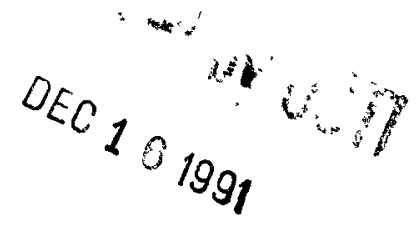

\begin{abstract}
Three types of moisture monitors: MCM Model Dewluxe-20, Panametrics Model System One, and Shaw Model SHA-TRS were tested for accuracy and speed of response over low (10-50 ppm $\mathrm{H}_{2} \mathrm{O}$ ), medium (100-500 ppm $\mathrm{H}_{2} \mathrm{O}$ ), and high (500-4,000 ppm $\mathrm{H}_{2} \mathrm{O}$ ) concentration ranges. The results for the three instruments tested (one of each kind) showed that the MCM instrument was generally more accurate and responded more quickly than the other two instruments, with the Panametrics instrument being less accurate (except at low concentration) and slower to respond, and the Shaw instrument was the least accurate and least responsive of the three instruments during the tests made.
\end{abstract}

\section{BACKGROUND}

A knowledge of the amount of water vapor that has passed through various pieces of equipment can be valuable in a tritium capture system, such as Mound's Tritium Emissions Reduction Facility (TERF). ${ }^{1}$ The concentration of water vapor in the gas stream and the flowrate determine how much must be removed by the dryers. The integrated amount of water collected indicates how much unused dryer capacity remains on dryers and how much longer they can be used before they must be regenerated.

Because levels of moisture and rates at which these concentrations vary with time are expected to differ widely at different points in the TERF, it might be desirable to use different types of moisture monitors in this system. An evaluation

*Mound is operated by EG\&G Mound Applied Technologies for the U.S. Department of Energy under contract No. DE-AC04-88-DP43495. of different types of moisture monitors was done in order to gain information as to which one would be the best for specific applications in the TERF.

\section{EQUIPMENT}

Moisture measurements need to be made against a calibrated standard in order to determine their accuracy. Provision of a standard was done by purchasing a General Eastern Chilled Mirror Humidity Analyzer and having its calibration checked and certified by Dr. John Hartley of the Sandia National Laboratories. This type of device is considered to be quite reliable and is often used as the standard in moisture measurements. ${ }^{2,3}$

The candidate moisture meters were plumbed in series with the chilled-mirror device. Then readings were taken simultaneously with these instruments in order to get comparisons between them. The three different instruments were tested in the work were:

1) an MCM Dewluxe-20 Si-Grometer, with 0-100 and 0-1000 ppm (vapor) scales;

2) a Panametrics System One; and

3) a Shaw Moisture Meter, Model SHA-TRS, with 0-1 and 0-1,000 ppm (vapor) scales.

Each of these types of instruments reads the electrical impedance of an electrode containing a layer of porous insulator between two electrodes. As moisture condenses in the pores, the electrical impedance is decreased. The higher the moisture content of gases to which the probe is exposed, the greater the amount of meter that adsorbs and the lower the impedance reading. ${ }^{3,4}$ The Panametric and Shaw units use a sensor based upon aluminum oxide, while the MCM units use a silicon oxide probe. 


\section{DISCLAIMER}

This report was prepared as an account of work sponsored by an agency of the United States Government. Neither the United States Government nor any agency Thereof, nor any of their employees, makes any warranty, express or implied, or assumes any legal liability or responsibility for the accuracy, completeness, or usefulness of any information, apparatus, product, or process disclosed, or represents that its use would not infringe privately owned rights. Reference herein to any specific commercial product, process, or service by trade name, trademark, manufacturer, or otherwise does not necessarily constitute or imply its endorsement, recommendation, or favoring by the United States Government or any agency thereof. The views and opinions of authors expressed herein do not necessarily state or reflect those of the United States Government or any agency thereof. 


\section{DISCLAIMER}

Portions of this document may be illegible in electronic image products. Images are produced from the best available original document. 
Each of these instruments was new when tested and had been calibrated by the manufacturer. It should be mentioned, however, that only one instrument of each type was used in these evaluations. The variation in results between different instruments of the same type was not tested.

\section{MEASUREMENTS}

The tests in this work were done at various moisture levels because the water concentration expected in the TERF varies from percent levels in the regeneration system down to less than one ppm in the system exhaust. Reliable tests are very difficult and time-consuming at low-ppm levels due to adsorption effects. To avoid these problems, the low level tests were done at concentrations well above $1 \mathrm{ppm}$. The testing procedures used in this work and the results obtained are described below. All results in this work are reported in parts per million by volume (ppm), which is the same as the molar concentration in parts per million.

\section{Tests At Low Moisture Concentrations}

The first test was run using a nitrogen gas cylinder as the source of gas. The concentration of moisture in the gas was measured using the General Eastern chilled-mirror system. During the two days of the tests, the moisture concentration decreased from 25 to 12 parts per million by volume. The results of the test including the date, time, and concentrations measured using the General Eastern, MCM, Panametrics, and Shaw instruments are listed in Table 1.

The data from Table 1 have been plotted in Figure 1 and show a comparison of them. The measurements were all made at discrete times, but are joined in the figure to show a smooth curve in each case, based upon the assumption that the concentration measured changed linearly between the times of the measurement.

None of the three test instruments picked up the initial drop in moisture concentration. The readings of the MCM instrument averaged approximately $40 \%$ low. The readings of the Panametrics instrument, with the exception of an excursion upwards during the middle of the run, averaged approximately $50 \%$ high. The Shaw measurements were essentially constant and averaged $65 \%$ low. None of the instruments did very well in this test, although the MCM instrument was the most accurate of the three, as can be seen by examination of these data as plotted in Figure 1.

\section{Test At Intermediate Moisture Concentrations}

In the intermediate moisture level (100-500 ppm) the test was done with moisture concentration. The data from this test are shown in Table 2 and Figure 2.

Table 1 - COMPARISON OF MOISTURE ANALYZERS LOW CONCENTRATIONS

\begin{tabular}{|c|c|c|c|c|c|c|}
\hline \multirow{2}{*}{$\begin{array}{l}\text { Obser- } \\
\text { vation } \\
\text { No. } \\
\end{array}$} & \multirow[b]{2}{*}{ Date } & \multirow[b]{2}{*}{ Time } & \multicolumn{4}{|c|}{ Moisture Concentration, ppm } \\
\hline & & & Standard & MCM & Shaw & Panametrics \\
\hline 1 & $11 / 22 / 88$ & 0930 & 25.7 & 7.2 & 4.0 & 22.1 \\
\hline 2 & & 0940 & 18.6 & 7.2 & 4.0 & 21.5 \\
\hline 3 & & 0950 & 14.1 & 7.3 & 4.0 & 21.5 \\
\hline 4 & & 1220 & 13.1 & 7.2 & 4.0 & 20.7 \\
\hline 5 & & 1230 & 13.6 & 7.2 & 4.0 & 20.7 \\
\hline 6 & & 1245 & 13.6 & 7.1 & 4.0 & 21.2 \\
\hline 7 & $11 / 23 / 88$ & 0840 & 13.9 & 6.0 & 4.5 & 26.4 \\
\hline 8 & & 1200 & 12.0 & 6.9 & 4.0 & 23.2 \\
\hline 9 & & 1250 & 11.7 & 7.0 & 4.0 & 19.9 \\
\hline 10 & & 1310 & 11.7 & 7.1 & 4.0 & 19.3 \\
\hline 11 & & 1440 & 11.7 & 7.2 & 4.0 & 18.8 \\
\hline 12 & & 1450 & 11.7 & 7.2 & 4.0 & 18.4 \\
\hline 13 & & 1500 & 11.7 & 7.3 & 4.0 & 18.4 \\
\hline 14 & & 1505 & 11.7 & 7.3 & 4.0 & 18.1 \\
\hline
\end{tabular}




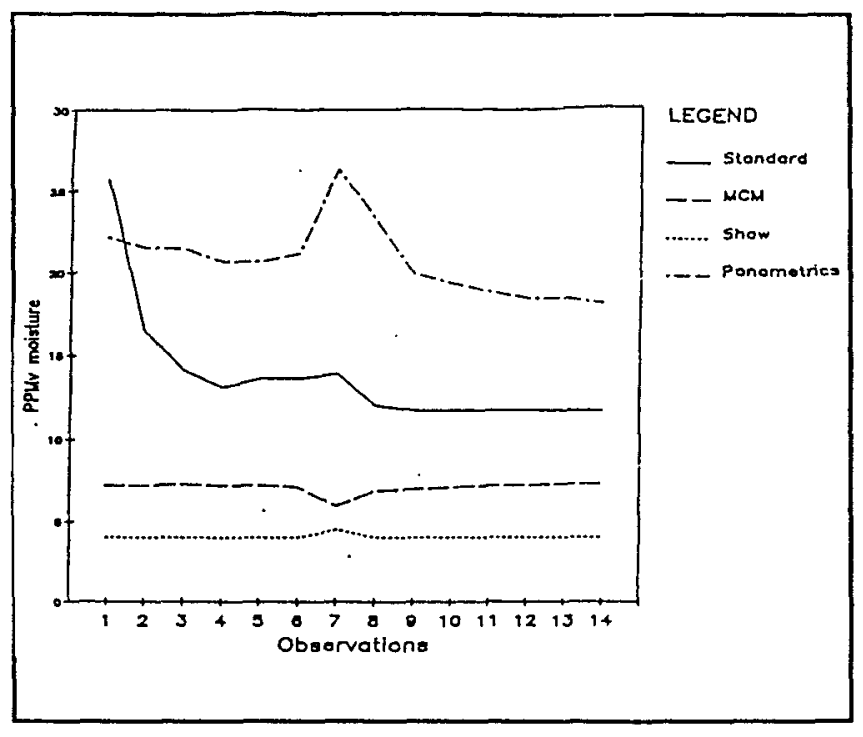

Figure 1 - Comparison of Moisture Analyzers Low Concentration.

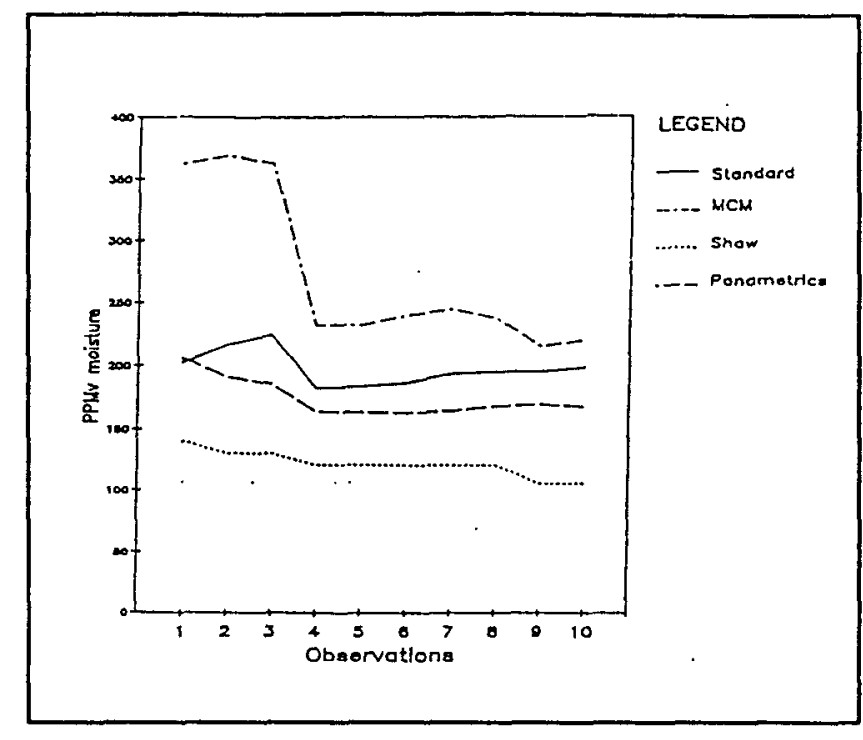

Figure 2 - Comparison of Moisture Analyzers Intermediate Concentration.

Table 2. COMPARISON OF MOISTURE ANALYZERS - INTERMEDIATE CONCENTRATIONS

\begin{tabular}{cccc}
$\begin{array}{c}\text { Obser- } \\
\text { vation } \\
\text { No. }\end{array}$ & Date & Time \\
\cline { 1 - 1 } & & & \\
1 & & $2 / 2 / 89$ & 1020 \\
2 & & 1310 \\
3 & & & 1445 \\
4 & & $2 / 3 / 89$ & 0630 \\
5 & & 0635 \\
6 & & 0810 \\
7 & & 1225 \\
8 & & 1515 \\
9 & & & \\
10 & & & 1105
\end{tabular}

Examination of Figure 2 shows that the MCM readings were the most accurate. Those of the Panametrics instrument were high for the first day, but finally came down to more reasonable levels. The Shaw instrument readings were consistently low.

\section{Moisture Concentration, ppm \\ Standard \\ Generator MCM Shaw Panametrics}

$\begin{array}{llll}202 & 205 & 140 & 362 \\ 216 & 191 & 130 & 369 \\ 224 & 186 & 130 & 362 \\ 182 & 164 & 120 & 232 \\ 184 & 163 & 120 & 232 \\ 186 & 163 & 120 & 239 \\ 194 & 165 & 120 & 244 \\ 195 & 168 & 120 & 237 \\ 195 & 169 & 105 & 215 \\ 198 & 167 & 105 & 220\end{array}$

Tests at Higher Moisture Concentrations

Tests were also run at relatively high concentrations, from 200 to 3,000 parts per million. These data are shown in Table 3 , and are plotted in Figure 3. 
Table 3. COMPARISON OF MOISTURE ANALYZERS - HIGHER CONCENTRATIONS

Obser-

vation

No. Date Time

$1 \quad 1 / 10 / 890630$

20635

30640

$4 \quad 1523$

$5 \quad 1 / 16 / 89 \quad 1600$

$6 \quad 1606$

$7 \quad 1615$

$8 \quad 1 / 17 / 89 \quad 0620$

$9 \quad 0637$

$10 \quad 0647$

$11 \quad 1145$

$12 \quad 1150$

$13 \quad 1 / 18 / 89 \quad 0615$

$14 \quad 1255$

$15 \quad 1302$

$16 \quad 1450$

$17 \quad 1507$

$18 \quad 1520$

$19 \quad 1 / 19 / 89 \quad 0630$

$20 \quad 1205$

\begin{tabular}{llll}
\multicolumn{4}{c}{ Moisture Concentration,ppm } \\
\hline Moisture & Standard $\quad$ MCM & Shaw & Panametrics
\end{tabular}

$\begin{array}{cc}206 & 188 \\ 206 & 198 \\ 206 & 215 \\ 234 & 242 \\ 367 & 373 \\ 367 & 376 \\ 368 & 373 \\ 384 & 376 \\ 386 & 380 \\ 1721 & 1897 \\ 2480 & 2110 \\ 2481 & 2113 \\ 1208 & 1235 \\ 1975 & 1860 \\ 2001 & 1696 \\ 2152 & 1826 \\ 3508 & 2815 \\ 3531 & 2482 \\ 2725 & 2570 \\ 3203 & 1760\end{array}$

$\begin{array}{ccc}190 & 125 & 227 \\ 190 & 125 & 229 \\ 190 & 125 & 229 \\ 202 & 175 & 266 \\ 415 & 290 & 455 \\ 415 & 290 & 455 \\ 414 & 290 & 450 \\ 363 & 280 & 393 \\ 364 & 288 & 393 \\ * * & 290 & 1298 \\ " & 310 & 1639 \\ " & 310 & 1654 \\ " & 300 & 1085 \\ " & * & 1347 \\ " & " & 1347 \\ " & " & 1387 \\ " & " & 1933 \\ " & " & 1846 \\ " & " & 1813 \\ " & " & 1426\end{array}$

* MLM System overload above 1000 PMMV

* Shaw did not respond to change in moisture level

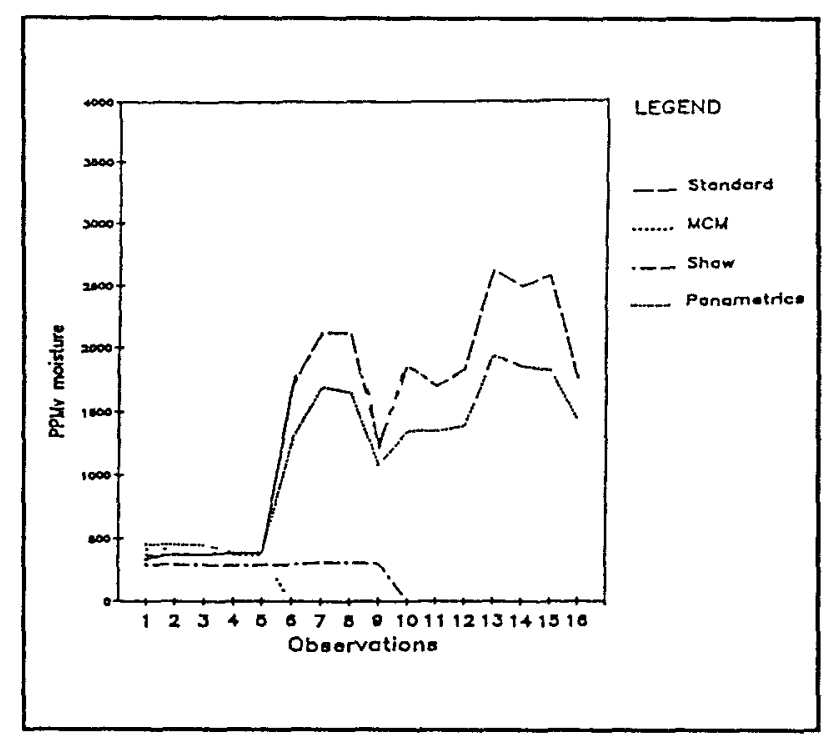

Figure 3 - Comparison of Moisture Analyzers Higher concentrations.
By referring to this figure, we see that the MCM instrument was the best in its agreement at the lowest part of the range. The MCM measurements were low by $8 \%$. The Panametrics measurements tended to be almost as good, being high by an average of 10 percent. The Shaw measurements were uniformly low by an average of approximately $\mathbf{4 0}$ percent.

As the readings approached 1,000 parts per million, both the MCM and Shaw instruments ceased to give readings since they were outside their designed region of operation. The Panametrics unit continued to give readings; however, they were considerably lower than those of the standard, in some cases by amounts exceeding 50 percent.

All of these tests were done with normal (protium) water. The water processed in the TERF is expected to contain tritium at concentrations of 100 to 1,000 curies per liter of liquid water. These 
concentrations are low enough that the radioactive contribution to the conduction of the absorbed water in the pores of the probe is expected to be not significant. Moisture probes used in such radioactive service at Mound have given readings below $1.0 \mathrm{ppm}$.

These tests indicated that: (1) the MCM instrument (which is the most expensive of the three test instruments) was generally the most accurate and responded fastest to concentration changes; (2) the Panametrics instrument (an intermediate-priced instrument) was less accurate and slower to respond to changes, except in the low concentration range, but its performance was close to that of the MCM; and (3) the Shaw instrument (the least expensive instrument) was the least accurate and the slowest to respond, but it could be used in some applications where accuracy and speed of response are not critical.

\section{CONCLUSIONS}

On the basis of these tests, it was decided to use both MCM and Panametrics instruments at different places in the TERF. The MCM instruments will be used in the first part of the process where the moisture concentrations are the highest and the most variable. The Panametrics instruments will be used for the last half of the process where the moisture concentrations are lower and less variable.

\section{REFERENCES}

1. Wieneke, R. E., et al, "Tritium Emissions Reduction Facility," Fusion Technology, 14, 899-903 (1988).

2. Gutierrez, R. L., "Calibration of Moisture Monitors," Los Alamos Scientific Laboratory, Report, LA 7696 (1979).

3. Mehrhoff, T. K., "Comparison of Continuous Moisture Monitors in the Range 1 to $15 \mathrm{ppm}, "$ Rev. Sci. Instrum. 56 (10), 1930 (1985).

4. Hasegawa, S., "Performance Characteristics of a Thin-Film Aluminum Oxide Humidity Sensor," Proceedings of the 30th Electronic Components Conference, p. 386 (1980).

\section{DISCLAIMER}

This report was prepared as an account of work sponsored by an agency of the United States Government. Neither the United States Government nor any agency thereof, nor any of their employees, makes any warranty, express or implied, or assumes any legal liability or responsibility for the accuracy, completeness, or usefulness of any information, apparatus, product, or process disclosed, or represents that its use would not infringe privately owned rights. Reference herein to any specific commercial product, process, or service by trade name, trademark, manufacturer, or otherwise does not necessarily constitute or imply its endorsement, recommendation, or favoring by the United States Government or any agency thereof. The views and opinions of authors expressed herein do not necessarily state or reflect those of the United States Government or any agency thereof. 